KS. WALDEMAR W. ŻUREK - LUBLIN

\title{
CENTRUM DOKUMENTACJI WSPÓLCZESNEJ SZTUKI SAKRALNEJ W UNIWERSYTECIE RZESZOWSKIM
}

18 II 2009 roku w Rzeszowie miała miejsce uroczysta inauguracja działalności Centrum Dokumentacji Współczesnej Sztuki Sakralnej utworzonego przy Pracowni Historii Sztuki - Wydziału Sztuki Uniwersytetu Rzeszowskiego. Działalność naukowa i badawcza Pracowni Historii Sztuki UR koncentruje się wokół zagadnień obejmujących swym zasięgiem polską sztukę sakralną XIX i XX wieku. Powołane Centrum Dokumentacji ma mieć głównie charakter archiwalno-informacyjny. Jego cele statutowe obejmą: pozyskiwanie i archiwizację dokumentacji sztuki sakralnej XIX i XX wieku dotyczącej zarówno twórców, jak poszczególnych obiektów i ich zespołów, mecenasów i inwestorów sztuki, nadto gromadzenie informacji na temat powstających prac naukowych (publikowanych i niepublikowanych) oraz udostępnianie posiadanych zbiorów do badań naukowych. Pomysłodawcą i kierownikiem Centrum została dr Grażyna Ryba, znany pracownik naukowy UR. Zapleczem dla powstającej instytucji była darowizna prof. Andrzeja Olszewskiego z Uniwersytetu Kardynała Stefana Wyszyńskiego, który przekazał swoje zbiory z 30-letniej pracy naukowo-badawczej na rzecz Uniwersytetu Rzeszowskiego. Przekazane zbiory zdeponowano w bibliotece uniwersyteckiej. Tam również będzie gromadziło i udostępniało swoje zbiory rzeszowskie Centrum.

$$
* * * * *
$$

Powołana instytucja naukowo-badawcza zainaugurowała swoją działalność podczas konferencji naukowej na temat: Dokumentacja sztuki sakralnej XIX $i$ XX wieku. Cele, metody, realizacja, która odbyła się w budynku użytkowanym przez Wydział Sztuki UR - w pałacu letnim Lubomirskich przy ul. Dekerta 2 w Rzeszowie. W czasie sesji naukowej przedstawiciele działających w Polsce instytucji naukowych, o pokrewnym do powstałego Centrum profilu, przedstawili historię, działalność i własne doświadczenia instytucji zajmujących się dokumentacją zbiorów naukowych w Polsce. 
Na program wspomnianej sesji złożyły się trzy referaty, wystawa obrazów, promocja pierwszego numeru pisma Sacrum et Decorum oraz nadzwyczajne zebranie Stowarzyszenia Ars sacra moderna połączone z wręczeniem dyplomów członków honorowych osobom szczególnie zasłużonym dla idei rozwoju badań nad sztuką sakralną w rzeszowskim ośrodku uniwersyteckim.

Na początek zabrała głos dr Grażyna Ryba pomysłodawca Centrum i organizator spotkania w Rzeszowie. Powitała przybyłych gości, przedstawiła kolejnych mówców i podziękowała władzom uczelni oraz wszystkim dzięki którym jej inicjatywa została sfinalizowana.

Jako pierwszy z gości zabrał głos biskup pomocniczy rzeszowski ks. Edward Białogłowski. Występując z upoważnienia pasterza diecezji rzeszowskiej - biskupa Kazimierza Górnego, w imieniu duchowieństwa rzeszowskiego i własnym podkreślił wagę i znaczenie sztuki sakralnej w lokalnym środowisku w którym żyjemy. Każdy człowiek, każde społeczeństwo - mówił hierarcha - potrzebuje kultury. Biskup Edward przywołał słowa Ojca Świętego Benedykta XVI wypowiedziane dnia 20 XII 2008 roku do wykładowców i studentów Papieskiego Instytutu Archeologii Chrześcijańskiej w Rzymie: „Rozpowszechnianie wiedzy o sztuce i historii we wszystkich grupach i społeczeństwach dostarcza współczesnym ludziom narzędzi pozwalających odnaleźć własne korzenie, które im pomogą nadać społeczeństwu prawdziwie ludzki wymiar". Powstałe Centrum będzie zajmować się sztuką współczesną inspirującą sacrum. Niech ta praca powołanego Centrum wydaje jak najlepsze owoce, życzył wszystkim zainteresowanym tą tematyką biskup.

Prorektor ds. Badań Naukowych i Współpracy z Zagranica, dr hab. Aleksander Bobko, witając zebranych powiedział, że jednym z ważnych źródeł poznania sztuki jest fascynacją. Pani doktor Ryba jest tą osobą, którą faktycznie cechuje fascynacja. Dzięki jej trosce i zabiegom doprowadzone zostało do pomyślnego końca powołanie Centrum. Rektor uczelni wręczył dr Grażynie Ryba dyplom do kierowania nową placówką naukową.

Dziekan Wydziału Sztuki UR poinformował, iż ten wydział posiada już 15. letnią historię, wcześniej jako wydział Wyższej Szkoły Pedagogicznej. W grudniu 2007 roku został wydzielony Wydział Sztuki na UR. Obecnie Wydział Sztuki zatrudnia 18 pracowników samodzielnych a studiuje na nim 370 studentów, w tym 142 na studiach stacjonarnych. W listopadzie 2007 roku z inicjatywy dr Grażyny Ryba zostało zorganizowane na UR pierwsze sympozjum poświęcone sztuce sakralnej. Utworzone Centrum jest jednostką samodzielną, posiadającą własne archiwum zapoczątkowane darem osobistego archiwum naukowego prof. Kazimierza Olszewskiego.

Do zebranych tego dnia w Rzeszowie przesłał list prezydent miasta, Tadeusz Ferens, który gratulował z racji powołania nowej instytucji naukowej zajmującej się ochroną i opieką sztuki sakralnej w naszym regionie. Przekazał również słowa uznania dla wszystkich osób zaangażowanych w powstanie Centrum.

W tonie gratulacyjnym przesłał list na ręce pani doktor Grażyny Ryba europoseł rzeszowski Mieczysław Janowski, wyrażając przy tej okazji radość, że mógł choć skromnie przyczynić się do powstania Centrum oraz do wydania pierwszego tomu pisma pod redakcja pani Ryby Sacrum et Decorum. 
W części referatowej, której przewodnictwo organizatorzy powierzyli prof. Kazimierzowi Olszewskiemu, jako pierwszy głos zabrał o. prof. dr hab. Józef Wanat, karmelita z Krakowa który mówił na temat: Źródła rękopiśmienne do sztuki sakralnej $w$ Polsce $w$ archiwach zakonnych. Odpowiadając na pytanie co to jest sztuka sakralna mówca podkreślił, iż w odróżnieniu od sztuki świeckiej ma ona charakter kościelny i związana jest z domem bożym. Za Janem Pawłem II powtórzył, że sztukę kościelną zalicza się do najszlachetniejszych dzieł ludzkich. W ramach sztuki sakralnej powstawała na przestrzeni wieków kościelna sztuka zakonna, regulowana własnymi przepisami zakonnymi. Zakony w Polsce mają wielki wkład w tworzenie sztuki sakralnej, głównie w okresie kontrreformacji. Ważne prawodawstwo na ten temat wydał Sobór Trydencki. Na zakończenie autor przedstawił rolę i znaczenie archiwów zakonnych w dokumentowaniu sztuki, w głównej mierze sakralnej.

Drugi z mówców ks. dr Waldemar Żurek z Lublina, występujący w zastępstwie ks. prof. dr hab. Anzelma Weissa przedstawił genezę powstania i działalność instytucji o pokrewnym profilu i działaniu co rzeszowskie Centrum - Instytutu Archiwów Bibliotek i Muzeów Kościelnych w Katolickim Uniwersytecie Lubelskim Jana Pawła II, w wystapieniu na temat: Wkład Instytutu Archiwów Bibliotek i Muzeów Kościelnych KUL w badaniach nad kultura polska. Powołany do życia w grudniu 1956 roku Ośrodek Archiwów, Bibliotek i Muzeów Kościelnych w Katolickim Uniwersytecie Lubelskim jako jeden z działów Biblioteki Głównej uczelni, od 1959 roku jest międzywydziałowym zakładem uniwersyteckim o charakterze usługowym. Od marca 2006 roku został przemianowany na Instytut Archiwów Bibliotek i Muzeów Kościelnych z siedzibą w Lublinie przy ul. Chopina nr 29. Od początku swej działalności Instytut realizuje swe zadania poprzez ewidencję zbiorów archiwalnych, bibliotecznych i muzealnych. Współpracuje z instytucjami kościelnymi i państwowymi odpowiedzialnymi za pieczę nad tymi zbiorami. Podejmuje szkolenie pracowników archiwów, bibliotek i muzeów kościelnych poprzez organizowane szkolenia i kursy specjalistyczne. Obecnie takie szkolenie kontynuuje poprzez sympozja naukowe w cyklu trzyletnim, poświęcone problematyce archiwalnej, bibliotecznej i muzealnej, których dotychczas odbyło się w Lublinie 34. Wydaje własne czasopismo - półrocznik Archiwa Biblioteki i Muzea Kościelne, którego tom 90 ukazał się w 2008 roku. Czasopismo wpisane na tzw. listę krajową. Lista prenumeratorów krajowych i zagranicznych liczy łącznie ponad 500 osób i instytucji. Zamieszcza artykuły opracowane głównie na materiałach źródłowych z dziedziny archiwalnej, bibliotecznej i muzealnej. W swej działalności Instytut (od 1960 roku) opracowuje (opisuje) i mikrofilmuje (obecnie także digitalizuje) materiały archiwalne i starodruki na usługi nauki, które gromadzi w formie mikrofilmów w bibliotece zakładowej, a ta liczy obecnie ponad 4.000 sygnatur ${ }^{1}$.

Ostatni z mówców przedpołudniowych, mgr Izabela Sosnowska-Kozieł z Orońska koło Radomia zapoznała zebranych z działalnością Centrum Rzeźby Polskiej w Orońsku: Działalność dokumentacyjna prowadzona w Centrum Rzeźby

\footnotetext{
${ }^{1}$ Opracowanie monograficzne: M. Dębowska, Ośrodek Archiwów Bibliotek i Muzeów Kościelnych Katolickiego Uniwersytetu Lubelskiego Jana Pawta II 1956-2006, Lublin 2006.
} 
Polskiej w Orońsku. Ten ośrodek prowadzi dokumentację archiwalną a obecnie także dokumentację komputerową polskich artystów, ich prac i zorganizowanych wystaw. Ta instytucja posiada status centrum muzealnego w Polsce. Funkcjonuje w nim biblioteka i archiwum slajdów.

Po części referatowej miało miejsce otwarcie wystawy malarskiej prac trzech artystów związanych z Wydziałem Sztuki i wykładowców UR: Stanisława Białogłowicza, Tadeusza Boruty i Tadeusza Wiktora pt. Wyrazić niewyrażalne. Prolog. W ramach wystawy przedstawione zostały trzy obrazy: Zapis ukryty Białogłowicza, Niewierny Tomasz Boruty ${ }^{2}$ i Modlitwa za ojca Wiktora ${ }^{3}$, reprezentujące trzy kierunki we współczesnej sztuce sakralnej. Kryterium doboru autorów wystawy podyktowała oryginalna odrębność twórców a każda z przedstawionych prac stanowiła odmienny temat. Wyczerpujący komentarz zapoznający słuchaczy z twórczością wymienionych trzech artystów wygłosiła dr Grażyna Ryba. Poinformowała zebranych iż plastyka rzeszowska najlepszy okres przeżywała w latach 60. ubiegłego stulecia. Dlatego powstające Centrum bazowało w małym stopniu na potencjale rodzimym, gdyż Rzeszów jeszcze nie zaistniał jako ośrodek twórców współczesnych. Wymienieni trzej autorzy wystawy wywodzą się z krakowskiego środowiska artystycznego. Studiowali na Akademii Sztuk Pięknych w Krakowie i zaliczani są do kategorii artystów religijnych, mimo że w swym dorobku artystycznym posiadają kilka dzieł o tej tematyce.

Swoje wystapienie dr Grażyna Ryba zakończyła stwierdzeniem, iż u współczesnych twórców sztuki dość wyraźnie występuje zjawisko marginalizacji sztuki sakralnej.

Ostatnim punktem programu była promocja pierwszego tomu rocznika Sacrum et Decorum. Materiaty i studia z historii sztuki sakralnej, periodyku o charakterze ogólnopolskim, którego potrzebę powstania postulowano od wielu lat. Wydawany jest w dwu wersjach językowych (polskiej i angielskiej) i rozpoczynającego działalność wydawniczą Centrum. Ten numer ukazał się dzięki licznym sponsorom, m.in. prezydentowi miasta Rzeszowa - Tadeuszowi Ferensowi, posłowi do Parlamentu Europejskiego - Mieczysławowi Janowskiemu oraz darczyńcom.

Powstały ośrodek Centrum, jako jedyny w tej części kraju (na Podkarpaciu), będzie rejestrował i dokumentował dzieła sztuki współczesnej, także sakralnej, by zapobiec ich zapominaniu lub niszczeniu, czego wszyscy sobie życzymy.

\footnotetext{
${ }^{2}$ Artysta mówi, że w jego twórczości malarskiej temat człowieka jest obecny od początku - zazwyczaj maluje tylko siebie. Interesuje go motyw przemiany - metanoia (Niewierny Tomasz, $\mathrm{Na}$ wrócenie się Szawła, Pentecoste, Upadek Aniołów, Otwarcie piatej pieczęci). T. Boruta, przemiany. Miejska Galeria Sztuki w Częstochowie, wrzesień - 2007, s. 3; A. Mickiewicz, T. Boruta, Leben verwundet, Pfarrkirche St. Kilian, Lechenich 22. Februar - 24. März 2008.

${ }^{3}$ Artysta posiada w swym dorobku szereg obrazów o podobnym tytule: Modlitwa za córkę, Modlitwa za syna, Modlitwa za siostrę, Modlitwa za Stefana Żeromskiego, Modlitwa za Bożenę Kowalska (żyje), Modlitwa za Eugenię (matkę). O swej twórczości Tadeusz Boruta mówi: „Sztuka jest wtedy istotna, jeśli odpowiada potrzebom duchowym człowieka".
} 